\title{
Optimization of soaking treatment on the quality of Pangasius fillet
}

\author{
*Ngoc, T.T.A., Sarnes, R. and Binh, L.N. \\ Food Technology Department, College of Agriculture, Can Tho University, Can Tho, Vietnam
}

\section{Article history:}

Received: 10 April 2020

Received in revised form: 14

July 2020

Accepted: 12 September 2020

Available Online: 27

December 2020

Keywords:

Pangasius fillets,

Phosphate,

Soaking conditions,

Sodium chloride,

Sorbitol.

\section{DOI:}

https://doi.org/10.26656/fr.2017.4(S6).002

\begin{abstract}
In Pangasius fillet industries, soaking fillet with food additives such as sorbitol, sodium tripolyphosphate (STPP) and sodium chloride $(\mathrm{NaCl})$ is a common practice to increase the quality of fillets. In this study, the fillets were soaked with different concentrations of sorbitol (1.32-4.68\%), STPP $(0.32-3.68 \%)$ and $\mathrm{NaCl}(1.32-4.68 \%)$ by using response surface methodology (RSM) with Central Composite Design with six replicates experimental design. The soaking solutions had a significant impact on weight gain, $\mathrm{pH}$ and water activity $(\mathrm{p}<0.05)$. The soaking solution of $\mathrm{NaCl} 1.32 \%$, STPP $1.88 \%$ and sorbitol $4.68 \%$ were optimal using multi-response optimizer. In addition, the optimum soaking time was studied from 15 to 60 mins. The results showed that soaking time should be appropriated for 30 mins. The optimum concentration and time of soaking can be considered as a practical pre-treatment to improve the quality of Pangasius fillets either for fresh, chilled, or frozen storage.
\end{abstract}

\section{Introduction}

Pangasius hypophthalmus, belongs to the family Pangasiidae commonly known as river or silver striped catfish in Mekong rivers (Rao et al., 2013). According to FAO (2019), Vietnam's farmed Pangasius industries become the largest in the world. Vietnam has been exported to more than 100 countries and territories, such as the EU, Brazil, USA, Australia and Canada. Although Vietnamese Pangasius fish products are marketed in several ways such as portions, steaks, fillets and its added-value products, frozen fillets and thawed fillets are the most popular form sold in supermarket and at fresh markets in Western countries (Orban et al., 2008).

Pangasius products are now largely accepted as an affordable substitute for cod and other more expensive white fishes (Orban et al., 2008; Phan et al., 2009; Karl et al., 2010). A good quality but highly perishable Pangasisus fillet has $12.9-15.7 \%$ protein, $1.3-3.2 \%$ fat, 0.8-1.3\% ash and $82.1-84.7 \%$ water (Karl et al., 2010; Phan et al., 2009).

Increasing demand for high-quality ready-to-cook Pangasius fillet with the extended shelf-life has initiated the development of several innovative techniques. There are several methods from low-temperature storage, nonthermal treatments, irradiation, the addition of preservatives, smoking, curing, modified atmosphere packaging (Esaiassen et al., 2005; Chouliara et al., 2007; Noseda et al., 2012; Davidson et al., 2013). In industry, soaking fillet with food additives such as sorbitol, sodium tripolyphosphate (STPP) and sodium chloride $(\mathrm{NaCl})$ is a common practice to increase the weight gain, the texture, the shelf life of meat, chicken fillet and fish fillet products (Park and Lanier, 1987; Smith and Acton, 2010; Yusop et al., 2011).

The addition of high STPP concentration can make an increase $\mathrm{pH}$ of fish products. Consequently, the shelf life of the product decreases and sensory failures due to sliminess, translucency, abused flavor and fat decomposition (Glorieux et al., 2017). Therefore, other food additives such as $\mathrm{NaCl}$ and sorbitol were often combined with STPP so that the concentration of STPP will be reduced. This study aimed to determine the optimum combination of STPP, $\mathrm{NaCl}$ and sorbitol which applied in the soaking solution of Pangasius fillet in order to improve the quality of Pangasius fillets.

\section{Materials and methods}

Trimmed Tra catfish (Pangasius hypopthalmus) $(150 \pm 10 \mathrm{~g} /$ fillet $)$ was purchased from Pangasius company in An Giang City, Vietnam. Then the samples were stored in ice and transported in insulated boxes to the Laboratory of Microbiology and Biotechnology of Food Technology Department, Can Tho University, 
Vietnam within 3 hrs. Food grade sodium tripolyphosphate (STPP) (France), sodium chloride $(\mathrm{NaCl})$ (Vietnam), sorbitol (France) were used for the soaking solution.

\subsection{Optimization of soaking concentration and time}

The effect of the soaking solution of $\mathrm{NaCl}(2-4 \%)$, STPP $(1-3 \%)$ and sorbitol $(2-4 \%)$ on the quality of Pangasius fillets was determined. Response surface methodology (RSM) with Central Composite Design with six replicates of the central point was used for the experimental design as shown in Table 1 by using Minitab 16, which resulted in forty randomized treatments.

Table 1. Experimental range and levels of the factors

\begin{tabular}{lccccc}
\hline \multirow{2}{*}{ Factors } & \multicolumn{5}{c}{ Range and levels } \\
\cline { 2 - 6 } & $-\alpha$ & Low & Medium & High & $+\alpha$ \\
\cline { 2 - 6 } & -1.68 & -1 & 0 & 1 & 1.68 \\
\hline $\mathrm{NaCl}$ & 1.32 & 2 & 3 & 4 & 4.68 \\
$\mathrm{STPP}$ & 0.32 & 1 & 2 & 3 & 3.68 \\
Sorbitol & 1.32 & 2 & 3 & 4 & 4.68 \\
\hline
\end{tabular}

The fillets were soaked in the solution at $4 \pm 1^{\circ} \mathrm{C}$ for 30 mins and drained of excess water in a strainer for 1 min. To find the optimum condition for the soaking concentration, the multi-response optimizer function in Minitab was used for prediction. The water activity was set at the minimum while the weight gain and sensory attributes were set at the maximum. The highest to the lowest importance level was set as follows: water activity, sensory (i.e. taste, odor and appearance), weight gain, color and texture.

The optimum soaking time of 15, 30, 45 and 60 mins was further investigated when the fillets were soaked at $4 \pm 1^{\circ} \mathrm{C}$ with the optimum concentration selected from the above experiment.

\subsection{Determination of physical properties}

The weight gain $(\mathrm{g} / 100 \mathrm{~g})$ was measured by weighing the sample before and after the immersion:

$$
\text { Weight gain }\left(\frac{g}{100 g}\right)=\frac{\text { mass }_{\text {after }}-\text { mass }_{\text {before }}}{\text { mass }_{\text {before }}} \times 100 \%
$$

The $\mathrm{a}_{\mathrm{w}}$ and $\mathrm{pH}$ of the homogenised were measured in duplicate by means of portable water activity meter (HygroPalm HP23, USA) and a pH-electrode (Metler Toledo, Schwerzenbach, Switzerland), respectively. Texture (hardness, $g$ force) was measured by Rheotex SD-305 (Japan). The color of samples was measured using a spectrophotometer-colorimeter (NR60CP, China). The color of 3 randomly chosen points was measured on each fillet. The overall color difference $(\Delta \mathrm{E})$ in color spaces $\mathrm{L}^{*}, \mathrm{a}^{*}$ and $\mathrm{b}^{*}$ was calculated according to the following equation and was reported by the equation (2).

$$
\Delta E=\sqrt{\left(L^{*}-L\right)^{2}+\left(a^{*}-a\right)^{2}+\left(b^{*}-b\right)^{2}}
$$

Where $\mathrm{L}^{*}, \mathrm{a}^{*}, \mathrm{~b}^{*}$ and $\mathrm{L}, \mathrm{a}, \mathrm{b}$ are the measured values of the samples on day 0 and day of sampling, respectively.

\subsection{Sensory evaluation}

Sensory evaluation was used to assess cooked fillets based on taste, odor and appearance as described by Howgate et al. (1992) and Meenakshi et al. (2010). The scoring scale ranges from 1 to 5 . The fillets were covered in foil and cooked in a steaming pot for 6 mins. Then, the fillets were cut into the same size and left to cool down before serving to the 20 panelists.

\subsection{Data analysis}

Statistical analysis was performed using Minitab 16 for windows (Minitab, LLC, Pennsylvania, USA). Oneway ANOVA was performed to analyze the optimization of soaking time. Tukey's multiple comparison was used to test for the differences among means with a significance level of $\alpha=0.05$.

\section{Results and discussion}

\subsection{Optimization of soaking solution}

\subsubsection{The effect of soaking to weight gain and $\mathrm{pH}$ of the fillets}

The concentration of $\mathrm{NaCl}$ and STPP had significant differences $(\mathrm{p}<0.05)$ in the weight gain of Pangasius fillet (Table 2, Figure 1). Thorarinsdottir et al. (2004) reported that the weight gain obtained using lower $\mathrm{NaCl}$ concentrations was more effective than a fully saturated brine solution. Also, according to Thorarinsdottir et al. (2004) the myofibrillar proteins rapidly lose water at a high salt concentration which causes the reduction of water holding capacity and consequently weight loss during soaking.

The concentration of STPP had a significant effect $(\mathrm{p}<0.05)$ on both $\mathrm{pH}$ and weight gain. Kin et al. (2010) reported that weight gain from soaking was predominantly depending on $\mathrm{pH}$. The STPP, an alkaline salt, induced to increase the water-holding capacity of foods (Lampila, 2013). The weight gain was not influenced by the concentration of sorbitol used (p>0.05). Ooizumi et al. (2004) reported that the osmotic pressure of the soaking solution prevented the dispersion of sorbitol and the migration of moisture during the soaking period. Especially, the cold soaking $\left(4^{\circ} \mathrm{C}\right)$ will make the sorbitol to disperse slowly on the surface equally; this resulted in protection and prevent protein denaturation of the fillet. 
Table 2. Effect of soaking concentration to physical properties of soaked Pangasius fillet

\begin{tabular}{|c|c|c|c|c|c|c|c|c|}
\hline \multirow{2}{*}{ Treatment } & \multicolumn{3}{|c|}{ Concentration (\%) } & \multicolumn{5}{|c|}{ Response } \\
\hline & $\mathrm{NaCl}$ & STPP & Sorbitol & Weight gain (\%) & $a_{w}$ & $\mathrm{pH}$ & Texture ( $\mathrm{g}$ force) & $\Delta \mathrm{E}$ \\
\hline 1 & 1.32 & 2 & 3 & 8 & 0.95 & 6.86 & 41.33 & 8.6 \\
\hline 2 & 1.32 & 2 & 3 & 8 & 0.94 & 6.82 & 31.3 & 14.82 \\
\hline 3 & 2 & 1 & 2 & 7.64 & 0.96 & 6.54 & 57 & 2.61 \\
\hline 4 & 2 & 1 & 2 & 7.64 & 0.99 & 6.58 & 50.75 & 3.16 \\
\hline 5 & 2 & 1 & 4 & 5.62 & 0.95 & 6.86 & 68.33 & 8.33 \\
\hline 6 & 2 & 1 & 4 & 5.62 & 0.96 & 6.69 & 68.33 & 2.09 \\
\hline 7 & 2 & 3 & 2 & 6.74 & 0.98 & 7.27 & 60 & 2.44 \\
\hline 8 & 2 & 3 & 2 & 6.74 & 0.96 & 6.95 & 53.67 & 7.18 \\
\hline 9 & 2 & 3 & 4 & 10.76 & 0.96 & 7.1 & 45.5 & 8.27 \\
\hline 10 & 2 & 3 & 4 & 8.1 & 0.99 & 6.91 & 37 & 2.73 \\
\hline 11 & 3 & 0.32 & 3 & 8.22 & 0.98 & 6.68 & 36.33 & 12.8 \\
\hline 12 & 3 & 0.32 & 3 & 8.22 & 0.97 & 6.39 & 46.33 & 1.18 \\
\hline 13 & 3 & 2 & 1.32 & 9.63 & 0.97 & 6.71 & 39.33 & 2.75 \\
\hline 14 & 3 & 2 & 1.32 & 9.63 & 0.98 & 6.84 & 32 & 10.6 \\
\hline 15 & 3 & 2 & 3 & 8.24 & 0.97 & 6.85 & 55.67 & 14.44 \\
\hline 16 & 3 & 2 & 3 & 8.24 & 0.97 & 6.58 & 52 & 6.18 \\
\hline 17 & 3 & 2 & 3 & 8.2 & 0.97 & 6.91 & 29 & 3.05 \\
\hline 18 & 3 & 2 & 3 & 9.2 & 0.98 & 6.89 & 56.67 & 5.91 \\
\hline 19 & 3 & 2 & 3 & 12.12 & 0.97 & 6.83 & 42 & 1.51 \\
\hline 20 & 3 & 2 & 3 & 9.66 & 0.96 & 6.8 & 62 & 13.43 \\
\hline 21 & 3 & 2 & 3 & 9.66 & 0.96 & 6.88 & 27 & 5.82 \\
\hline 22 & 3 & 2 & 3 & 12.86 & 0.97 & 6.88 & 55.67 & 3.05 \\
\hline 23 & 3 & 2 & 3 & 8 & 0.95 & 6.93 & 43 & 3.94 \\
\hline 24 & 3 & 2 & 3 & 9.2 & 0.95 & 6.91 & 62.5 & 3.89 \\
\hline 25 & 3 & 2 & 3 & 8 & 0.95 & 7.28 & 67 & 3.9 \\
\hline 26 & 3 & 2 & 3 & 11.65 & 0.96 & 6.84 & 56.25 & 1.75 \\
\hline 27 & 3 & 3.68 & 3 & 9.71 & 0.98 & 7.35 & 35 & 4.62 \\
\hline 28 & 3 & 3.68 & 3 & 8.4 & 0.96 & 7 & 35.67 & 4.47 \\
\hline 29 & 3 & 2 & 4.68 & 7.19 & 0.94 & 6.75 & 66 & 3.76 \\
\hline 30 & 3 & 2 & 4.68 & 7.19 & 0.96 & 6.83 & 41.33 & 0.88 \\
\hline 31 & 4 & 1 & 2 & 8.28 & 0.99 & 6.9 & 55 & 1.28 \\
\hline 32 & 4 & 1 & 2 & 9 & 0.97 & 6.58 & 55 & 0.58 \\
\hline 33 & 4 & 1 & 4 & 8.12 & 0.97 & 6.77 & 36.25 & 1.36 \\
\hline 34 & 4 & 1 & 4 & 8.12 & 0.97 & 6.85 & 67 & 1.67 \\
\hline 35 & 4 & 3 & 2 & 7.77 & 0.96 & 6.87 & 21 & 0.93 \\
\hline 36 & 4 & 3 & 2 & 7.77 & 0.97 & 6.69 & 48.5 & 3.26 \\
\hline 37 & 4 & 3 & 4 & 9.33 & 0.97 & 6.75 & 34 & 3.04 \\
\hline 38 & 4 & 3 & 4 & 11.29 & 0.96 & 7.22 & 34 & 1.2 \\
\hline 39 & 4.68 & 2 & 3 & 9.62 & 0.95 & 6.71 & 38 & 1.39 \\
\hline 40 & 4.68 & 2 & 3 & 6.94 & 0.94 & 6.85 & 24.5 & 2.2 \\
\hline
\end{tabular}

In addition to STPP, sorbitol caused an increase of osmotic pressure in the fillet. The higher concentration of sorbitol resulted in the lower water activity of the fillets because the low molecular weight of sorbitol had the dewatering effect on the fillets. The contradicting properties of STPP and sorbitol should be considered in soaking the fillets. Accordingly to Ooizumi (2004), the combination of high sorbitol concentration and low STPP concentration will result in the lowest yield of soaked Pangasius fillet.

3.1.2 The effect of soaking to water activity $\left(a_{w}\right)$ of the fillets

$\mathrm{a}_{\mathrm{w}}$ is the water that is not bound to food molecules; it impacts greatly on the growth of bacteria, yeasts and molds (Ghaly et al., 2010). Therefore, the control of water activity is one of the good preventions to inhibit the fish spoilage. In this study, water activity was affected by $\mathrm{NaCl}$ and sorbitol $(\mathrm{p}<0.05)$. According to Abbas et al. (2009), the solution of salt and sugar caused a reduction of $a_{w}$ of the fillets. Thus, the water in the fillets became less available for microbial growth. Fig.1 shows that the higher concentration of sorbitol used in soaking resulted in lower $a_{w}$ of the fillets observed. Sorapukdee et al. (2016) explained that sorbitol is considered as a humectant, which has a major role in reducing water activity in food substances. The sorbitol showed a significant effect compared to $\mathrm{NaCl}$ and STPP because the sorbitol has higher solubility in water. The 

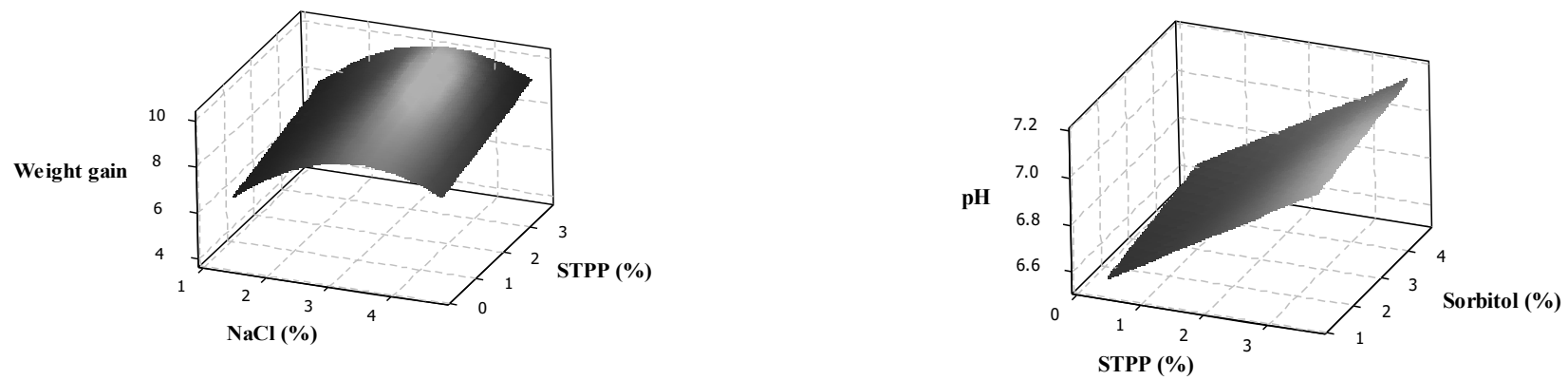

Surface plot of water activity

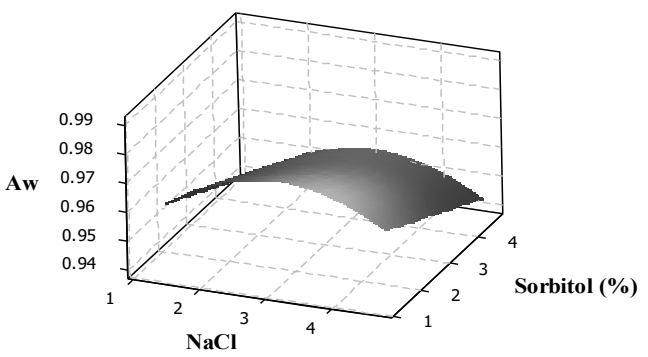

Figure 1. Effect of soaking concentration to the treated Pangasius fillets

increase of $\mathrm{a}_{\mathrm{w}}$ was observed when the fillets were soaked in $\mathrm{NaCl} 1-3 \%$ followed by the decrease of $\mathrm{a}_{\mathrm{w}}$ was obtained at higher concentration of $\mathrm{NaCl}$ soaked. This can be referred to the $\mathrm{NaCl}$ gained by the fillets as explained a previous study conducted by Thorarinsdottir et al. (2004).

\subsubsection{The effect of soaking to the texture and color of the fillets}

There was no significant effect on the texture and overall of color of the fillets ( $p>0.05)$ among studied concentrations as shown in Table 2. In addition, the sensory attributes of the fillets (i.e. odor, appearance and taste) were not a significant difference (data not shown). The addition of various concentrations of STPP, $\mathrm{NaCl}$ and sorbitol did not give any negative impact on those parameters of the treated Pangasius fillets.

From the response optimizer, this study aimed to increase the quality of soaked fillets. Therefore, weight gain and sensory attributes was targeted at maximum while water activity at a minimum. It was found that the optimum point was $1.32 \%$ of $\mathrm{NaCl}, 1.88 \%$ of STPP and $4.68 \%$ of sorbitol concentration with composite desirability of 0.9 . Therefore, these concentrations were further used to determine the optimum soaking time with the same soaking condition at $4 \pm 1^{\circ} \mathrm{C}$.

\subsection{Optimization of soaking time}

In this study, the variation of soaking time only shows significant differences in weight gain and sensory attributes (i.e. odor and taste) $(\mathrm{p}<0.05)$ as shown in Table 3.

The weight gain increased over time, especially from 15 to 30 mins. In order to diffuse into the fibers and myofibril matrices, the solution must destroy physical barriers or constraints in muscle such as sarcolemma and actin myosin cross-linkages (Ooizumi et al., 2004). The high gradient between outside and inside muscle tissue contributed to a fast weight gain during soaking. In this study, the optimum weight gain can be reached after 30 mins. As the water can be chemically bonded or physically entrapped in the muscle, it leads to the gain weight to reach maximum. The slow rate of absorption was observed when the available water was reduced during soaking (Ooizumi et al., 2004; Yusop et al., 2011)

In contrast, soaking time from $15-60$ mins did not give a significant difference in texture, water activity, $\mathrm{pH}$, color (data not shown) and appearance (Table 3). STPP, a texturizer, can maintain the protein and the moisture of the fillets which resulted in a more stable texture. The results of this study were in agreement with a study of Crapo and Crawford (1991) who observed that crab meat soaked in polyphosphate for 30-60 mins can improve the yield whereas the texture of crab meat was no significant improvement. As can be seen in Table 3, the appearance was no significant difference, but the odor and taste were significant difference during soaking 
Table 3. The effect of soaking time to weight gain, odor, taste, and appearance of Pangasius fillet

\begin{tabular}{ccccc}
\hline Time & Weight gain $(\%)$ & Odor & Taste & Appearance \\
\hline 0 & - & $3.37^{\mathrm{c}}$ & $2.75^{\mathrm{b}}$ & $3.37^{\mathrm{a}}$ \\
15 & $5.38 \pm 0.29^{\mathrm{b}}$ & $3.84 \pm 0.09^{\mathrm{bc}}$ & $3.35 \pm 0.35^{\mathrm{ab}}$ & $3.78 \pm 0.31^{\mathrm{a}}$ \\
30 & $8.92 \pm 0.38^{\mathrm{a}}$ & $4.11 \pm 0.16^{\mathrm{ab}}$ & $3.55 \pm 0^{\mathrm{ab}}$ & $3.93 \pm 0.25^{\mathrm{a}}$ \\
45 & $10.83 \pm 0.80^{\mathrm{a}}$ & $4.12 \pm 0.01^{\mathrm{ab}}$ & $3.77 \pm 0.15^{\mathrm{ab}}$ & $4.31 \pm 0.09^{\mathrm{a}}$ \\
60 & $11.43 \pm 0.98^{\mathrm{a}}$ & $4.39 \pm 0.01^{\mathrm{a}}$ & $3.89 \pm 0.01^{\mathrm{a}}$ & $3.94 \pm 0.08^{\mathrm{a}}$
\end{tabular}

Values followed by the different letter within the same row are significantly different from each other $(\mathrm{p}<0.05)$.

time. The higher sensory scores of cooked fillets were seen when the soaking time was longer. The fillets soaked for $15 \mathrm{~min}$ had no significant differences in odor with the control samples. After soaking for 30 mins, the odor score increased but it was not significant up to 60 mins. Therefore, in terms of efficiency, the soaking is recommended for 30 mins.

\section{Conclusion}

The optimum conditions were $1.32 \%$ of $\mathrm{NaCl}$, $1.88 \%$ of STPP and $4.68 \%$ of sorbitol concentration using the response surface methodology. The improvement of yield and sensory of Pangasius fillets can be obtained when the Pangasius fillets were soaked for $30 \mathrm{~min}$ at $4 \pm 1^{\circ} \mathrm{C}$.

\section{Acknowledgment}

The authors would like to gratefully acknowledge the Vlir-ous and Can Tho University Improvement Project, VN14-P6 supported by Japanese ODA loan for the administrative and financial support.

\section{References}

Abbas, K., Saleh, A., Mohamed, A. and Lasekan, O. (2009). The relationship between water activity and fish spoilage during cold storage: A review. Journal of Food, Agriculture and Environment, 7(3/4), 8690. https://doi.org/10.1016/j.fm.2006.12.005

Chouliara, E., Karatapanis, A., Savvaidis, I. and Kontominas, M. (2007). Combined effect of oregano essential oil and modified atmosphere packaging on shelf-life extension of fresh chicken breast meat, stored at $4^{\circ} \mathrm{C}$. Food Microbiology, 24(6), 607-617. https://doi.org/10.1016/j.fm.2006.12.005

Crapo, C.A. and Crawford, D.L. (1991). Influence of polyphosphate soak and cooking procedures on yield and quality of dungeness crab meat. Journal of Food Science, 56(3), 657-659. https://doi.org/10.1111/ j.1365-2621.1991.tb05350.x

Davidson, P.M., Taylor, T.M. and Schmidt, S.E. (2013). Chemical preservatives and natural antimicrobial compounds. In Doyle, M.P. and Buchanan, R.L. (Eds.) Food microbiology. American Society of
Microbiology. $4^{\text {th }}$ ed., p. 765-801. UK: Wiley Online Library. doi.org/10.1128/9781555818463.ch30

Esaiassen, M., Østli, J., Joensen, S., Prytz, K., Olsen, J.V., Carlehög, M., Elvevoll, E.O. and Richardsen, R. (2005). Brining of cod fillets: effects of phosphate, salt, glucose, ascorbate and starch on yield, sensory quality and consumers liking. $L W T$ Food Science and Technology, 38(6), 641-649. https://doi.org/10.1016/j.lwt.2004.08.011

FAO. (2019). Food and Agricultural Organization (FAO). Viet Nam on track for USD 2 billion annual pangasius export target as high prices continue. Retrieved July 05, 2019 from FAO website: www.fao.org/in-action/globefish/market-reports/ resource-detail/en/c/1176222/.

Ghaly, A.E., Dave, D., Budge, S. and Brooks, M.S. (2010). Fish spoilage mechanisms and preservation techniques: Review. American Journal of Applied Sciences, 7(7), 859-877.

Glorieux, S., Goemaere, O., Steen, L. and Fraeye, I. (2017). Phosphate reduction in emulsified meat products: Impact of phosphate type and dosage on quality characteristics. Food Technology and Biotechnology, 55(3), 390-397. https:// doi.org/10.17113/ftb.55.03.17.5089

Howgate, P., Johnston, A. and Whittle, K. (1992). Multilingual guide to EC freshness grades for fishery products. USA: West European Fish Technologists' Association (WEFTA) 1992.

Karl, H., Lehmann, I., Rehbein, H. and Schubring, R. (2010). Composition and quality attributes of conventionally and organically farmed Pangasius fillets (Pangasius hypophthalmus) on the German market. International Journal of Food Science and Technology, 45(1), 56-66. https://doi.org/10.1111/ j.1365-2621.2009.02103.x

Kin, S., Schilling, M., Smith, B., Silva, J., Jackson, V. and Kim, T. (2010). Phosphate type affects the quality of injected catfish fillets. Journal of Food Science, 75(1), S74-S80. https://doi.org/10.1111/ j.1750-3841.2009.01433.x 
Lampila, L.E. (2013). Applications and functions of food -grade phosphates. Annals of the New York academy of Sciences, 1301(1), 37-44.

Meenakshi, V., Narayanan, K. and Venkataraman, R. (2010). Evaluation of organoleptic and biochemical status of the fish, Cyprinuscarpio at different storage temperatures. Journal of Biomedical Sciences and Research, 2(4), 254-257.

Noseda, B., Islam, M.T., Eriksson, M., Heyndrickx, M., De Reu, K., Van Langenhove, H. and Devlieghere, F. (2012). Microbiological spoilage of vacuum and modified atmosphere packaged Vietnamese Pangasius hypophthalmus fillets. Food Microbiology, 30(2), 408-419. https:// doi.org/10.1016/j.fm.2011.12.025

Ooizumi, T., Tsuruhashi, K., Miono, Y. and Akahane, Y. (2004). Control of sugar content in fish fillets by soaking and cold preservation. Developments in Food Science, 42, 415-423. https://doi.org/10.1016/ S0167-4501(04)80041-4

Orban, E., Nevigato, T., Lena, G.D., Masci, M., Casini, I., Gambelli, L. and Caproni, R. (2008). New trends in the seafood market. Sutchi catfish (Pangasius hypophthalmus) fillets from Vietnam: Nutritional quality and safety aspects. Food Chemistry, 110(2), 383-389.

https://doi.org/10.1016/ j.foodchem.2008.02.014

Park, J.W. and Lanier, T.C. (1987). Combined effects of phosphates and sugar or polyol on protein stabilization of fish myofibrils. Journal of Food Science, 52(6), 1509-1513. https://doi.org/10.1111/ j.1365-2621.1987.tb05866.x

Phan, L.T., Bui, T.M., Nguyen, T.T., Gooley, G.J., Ingram, B.A., Nguyen, H.V., Nguyen, P.T. and De Silva, S.S. (2009). Current status of farming practices of striped catfish, Pangasianodon hypophthalmus in the Mekong Delta, Vietnam. Aquaculture, 296(3), 227-236. https:// doi.org/10.1016/j.aquaculture.2009.08.017

Rao, B.M., Murthy, L.N. and Prasad, M. (2013). Shelf life of chill stored pangasius (Pangasianodon hypophthalmus) fish fillets: effect of vacuum and polyphosphate. Indian Journal of Fisheries, 60(4), 93-98.

Smith, D.P. and Acton, J.C. (2010). Marination, cooking and curing of poultry products. In Owens, C.M., Alvarado, C.Z. and Sams, A.R. (Eds.) Poultry Meat Processing. $2^{\text {nd }}$ ed., p. 2257-280. Boca Raton: CRC press.

Sorapukdee, S., Uesakulrungrueng, C. and Pilasombut, K. (2016). Effects of humectant and roasting on physicochemical and sensory properties of jerky made from spent hen meat. Korean Journal for Food Science of Animal Resources, 36(3), 326. https:// doi.org/10.5851/kosfa.2016.36.3.326

Thorarinsdottir, K.A., Arason, S. Bogason, S.G. and Kristbergsson, K. (2004). The effects of various salt concentrations during brine curing of cod (Gadus morhua). International Journal of Food Science and Technology, 39(1), 79-89. https://doi.org/10.1046/ j.0950-5423.2003.00757.x

Yusop, S.M., O’Sullivan, M. and Kerry, J. (2011). Marinating and enhancement of the nutritional content of processed meat products. In Kerry, J.P. and Kerry, J.F. (Eds.) Processed Meats., p. 421-449. USA: Woodhead Publishing Limited. https:// doi.org/10.1533/9780857092946.3.421 